\title{
THE AUTO-DECONSTRUCTIVE IMAGE: OF VESTIGIAL PLACES
}

\author{
ALENA ALEXANDROVA
}
Was there ever any such "past world" of naïve and imaginary belief? Is this not rather our retrospective illusion, we who always want to have a past that has been surpassed, or perhaps lost...? (Jean-Luc Nancy, Visitation, p. 123)

\section{Opening Within - Dis-enclosure}

The deconstruction of Christianity is an ongoing project for Jean-Luc Nancy. Apart from La Déclosion (2005a), the book which contains the central texts he has written on this topic, themes and ideas pertaining to that project persistently appear in his earlier writings on visual art, where he places art at the heart of such deconstruction. ${ }^{1}$ For a clearer understanding of its multiple aspects, it is important to trace the way in which Nancy thinks the notions of image and representation, and shows their limits, in terms of their intricate relationship with their monotheist provenance.

A key aspect of Nancy's project as a whole consists in rethinking our secular condition with a view to a re-evaluation of the effects of its religious provenance on the basis of an emphatic engagement with the present. As Nancy notes: 'a "provenance" [...] is never simply a past: it informs the present; it ceaselessly produces its own effects' (Nancy, 2003: 38). The deconstruction of Christianity cannot take place in the form of a mere historical analysis.

\footnotetext{
${ }^{1}$ Such themes virtually appear in all the essays included in The Muses (1997), The Ground of the Image (2005), and the 'Look of the Portrait' (2006). Footnote 4 in 'The Image. The Distinct' reads: 'But in the second direction [the direction of what Nancy identifies as sacrificial image, as sacrifice understood as an image, the Eucharistic 'sacred species', AA] sacrifice deconstructs itself, along with all monotheism. The image - and with it art in general - is at the heart of this deconstruction' (Nancy, 2005c: 140).
} 
Instead, it should be understood as directed at showing the internal tensions within Christianity as a system of ideas (or as Nancy puts it: an assemblage of ideas), which is already engaged in undermining itself as a system. To deconstruct Christianity would mean: "neither to destroy in order to refound nor to perpetuate - theses that imply system given and unaffected as such', but to 'loosen up the assembled structure' in order to bring to light the various possibilities covered over by that structure (Nancy, 2001: 121). ${ }^{2}$ Such an operation is possible only from within the tradition that is deconstructed and consists in tracing the implications of how it relates to itself. In other words, deconstruction is an aspect of the very structure deconstructed and not an exterior operation applied to it. According to Nancy, this relationship that it has with itself is a continuous movement of self-overcoming: Christianity relates 'to its own origins as to a play, an interval, a break, an opening up in origin' (Nancy, 2001: 122).

An important aspect of such an effort to show the effects of how Christianity relates to itself and its own origins, is the analysis of how it situates itself within metaphysics. Nancy suggests that Christianity (and monotheism with it) can be considered a powerful confirmation of metaphysics, to the extent that it rests on a founding presence that guarantees the world and which is situated beyond it (Nancy, 2005: 16-7). This moment of claiming, or demanding, a supreme presence beyond this world, a being that guarantees the world, but which is itself inaccessible - or rather is accessible, but only to itself - is in fact the moment of auto-constitution of both metaphysics and Christianity. This mode of auto-reference can be viewed as a tautological relationship, i.e. Christianity thinks of itself in relation to itself. However, such a state of closure, or complete auto-determination, is at the same time the greatest point of indeterminacy. As Nancy points out, metaphysics contains within itself the movement of its own destabilisation, i.e. it deconstructs itself constitutively. With regards to rational thought, Nancy emphasises the need to pose not only the question of the alter (the relational other within a couple), but also that of the allos, the entirely other (Nancy, 2005: 15). The notion of allos can be understood as a figure of indeterminacy, since it cannot be appropriated or named, but also because it is indeterminate to itself. In monotheism, God - who is allos - is an inaccessible presence beyond this world, a point of absolute autodetermination, a founding presence, but simultaneously also a figure of a

\footnotetext{
2 See the introduction of Devisch and Van Rooden in this volume for an extended discussion of the main aspects of this project.
} 
rupture, an opening within, a dis-enclosure (Nancy, 2005: 16-7). Within monotheism, the Christian God is an intriguing playing out of what can be called an allo-auto relationship with itself and with the world. Here, the allos should not be thought of as something that is completely withdrawn, but rather as the auto-, as a mode of relationship of man with himself, as the incarnate God who is present in the image of man.

\section{Invisible - Indivisible}

According to Nancy, the dynamics of how Christianity relates to itself, the movement of auto-deconstruction, can be better understood if it is considered in the context of distinguishing between polytheism and monotheism. A decisive aspect of the difference between them lies in how these two different religious modes articulate the possibility of representation of the divine. A discussion of this issue will shed more light on Nancy's claim that art is at the heart of the auto-deconstruction of Christianity and monotheism.

In 'Deconstruction of Monotheism', Nancy writes that Christianity - as a monotheist religion - has a history of understanding itself in an increasingly less religious manner in the sense that it no longer holds on to a mythology, or representation, of divinities and their actions (Nancy, 2003: 42). Central to this movement of demythologisation, or atheisation, is the rejection of the presence of gods in this world. In contrast to the effective presence of a plurality of gods that organises the world 'via the totality of its myths and its rites' (Nancy, 2003: 42), the monotheist God withdraws from the world. This radical absence is substituted by negative formulas affirming his invisibility and unrepresentability. However, Nancy further complicates this picture in The Creation of the World or Globalization by suggesting that this movement of atheisation of monotheism, the withdrawal of God from the world, actually results in what he calls an absentheistic world, i.e. a "world without God, that is to say without another world' (Nancy, 2007: 50, my emphasis AA).

Traditionally, the invisibility of the monotheist God has been associated with a ban on the graven image, whose most formal expression is to be found in Exodus. ${ }^{3}$ The universal God is 'a jealous God' who withdraws into invisibility, thereby making himself absolutely distinguishable from the false gods of the

\footnotetext{
3 'You shall not make for yourself a graven image, or any likeness of anything that is in heaven above, or that is in the earth beneath, or that is in the water under the earth; you shall not bow down to them or serve them; for I the Lord your God am a jealous God, visiting the iniquity of the fathers upon the children to the third and the fourth generation of those who hate me' (Exodus 20: 4-6).
} 
idols. ${ }^{4}$ In an essay entitled 'The Look of the Portrait', Nancy points out that the plurality of gods 'constitutes their visibility, whether potential or actual, as well as their presence' and consequently 'the art of polytheism provides a vision of the gods' (Nancy, 2005: 240, my emphasis AA). In contrast, monotheism is characterised by the 'indivisibility of God withdrawn into His unity' (Nancy, 2005: 241, my emphasis AA). Introducing a nuance in the traditional interpretation, he suggests that what is central to monotheism is not the unity of God, since that unity is not a result of a simple reduction in the number of gods, but indivisibility as an essential property of this unity (Nancy, 2005: 240). ${ }^{5}$ Nancy's emphasis on God's indivisibility rather than his invisibility, is a result of the strategy he uses in his analysis of the auto-deconstructive aspects of monotheism. In his view, as mentioned above, monotheism deconstructs itself precisely because it is engaged in a relationship with itself. The presence of God in-himself and for-himself amounts to his inaccessibility and the immediate consequence of this movement of auto-determination is his unity or indivisibility. As a result, the mono- of the one God, if we accept Nancy's line of thinking, is not the outcome of his uniqueness and universality, but of his relationship with himself.

In The Creation of the World or Globalization (2007), Nancy suggests that the theological notion of 'creation' offers another way of thinking about the autorelationship of the monotheist God and which constitutes a key moment in the auto-deconstruction of monotheism. Creation, and in particular, creation ex nihilo, is the opposite of a production, or 'fabrication', which presupposes a producer and a model. Creation ex nihilo does not mean that the world is 'fabricated with nothing', nor does it mean that it comes 'out of nothing (like a miraculous apparition)' (Nancy, 2007: 51, my emphasis AA). Instead, it is the 'nothing' that grows in creation and which 'takes care of itself' (Nancy, 2007: 51). Creation is self-creation, it is dissociated from a producer, model or origin, and most importantly: 'The ex nihilo is the genuine formulation of a radical materialism, that is to say precisely, without roots' (Nancy, 2007: 51). It is a radical materialism, because the nihil of creation of the world is its proper 'matter'.

Nancy argues that in the act of creation 'God annihilates itself [s'annéantit] as a "self" or as a distinct being in order to "withdraw" in its act - which makes the opening of the world' (Nancy, 2007: 70, my emphasis AA). The act of

\footnotetext{
${ }^{4}$ See Hans Belting, Likeness and Presence. A History of the Image before the Era of Art, p. 7.

5 This argument also appears in 'Deconstruction of Monotheism' (2003) and The Creation of the World (2007).
} 
creation constitutes God's indivisibility, because he merges with the act of creation, rather than preceding it as a producer. Such withdrawal of any given, or origin, is central to the motif of creation, which is precisely the point where monotheism distinguishes itself from the mythological mode as related to a pre-given foundational myth. The monotheist God creates without a model and by emptying himself in that creation, he coincides with the world (Nancy, 2007: 69-70). In Nancy's view, the theme of the indivisibility of the monotheist God should not be understood as a reduction in number - there is only one God - but the mono must also be understood in terms of a God who is first and foremost indivisible in and for himself, as well as from the world. Nancy adds that theology has in fact gradually stripped itself from a God who is distinct from the world (Nancy, 2007: 50) and he refers to the moment of the coincidence or indivisibility between God and the world as absentheism. In this way, indivisibility is connected with the invisibility of the monotheist God, but not in the sense that he is inaccessible to human eyes. According to Nancy's interpretation, such invisibility is a result of the very coincidence of God with the world.

This withdrawal through indivisibility creates a specific agenda for the image and defines art as one of the places of God's withdrawal. Insofar as monotheism is an atheism, or a complete metamorphosis of the divine, Nancy insists that there is no God, but only places (Nancy, 2007: 69). This theme appears in 'The Look of the Portrait', where he discusses the effects that the indivisibility of God has on the image. The art of the icon becomes an art of a negative theology, i.e. an art that presents the absenting, the withdrawal of God:

\footnotetext{
'The icon exposes the invisible; not by rendering it properly visible but by exposing the presence of the invisible, calling thereby for a vision other than that of sight. The invisible God is not simply situated away from our eyes; rather, He is invisible in and for Himself [...].In truth, the one God is less invisible (in the sense of being hidden) than nonappearing; far from being a matter of making this non-appearance appear (this nonappearance considered as the very act of God, his modus operandi, so to speak), it has to be a matter of presenting its presence, which is itself absence. Equally, the iconic figure is not a visage but a face; it exposes the non-appearing face of the whole of the visible' (Nancy, 2006: 241, my emphasis AA).
}

In Nancy's interpretation, art is defined by a negative moment - its proper subject would be the inaccessibility of God, and its task the figuration of that inaccessibility. However, when seen in light of the description above, this impossible task is not a result of the invisibility of God - it is determined by his indivisibility from the world. If the creation ex nihilo is a formula of a radical materialism (since the 'nothing' is the very matter of the world), then 
the image shows nothing else but that indivisibility - it presents itself in its materiality.

Seen from this perspective, the notion of creation as discussed by Nancy is not only a key point in the auto-deconstruction of monotheism, it is also central to the Western self-understanding of art. If religious art is the testimony of the void of creation, as well as the double indivisibility of God, then art and in particular the image, regardless of whether it has a religious subject or not, will always echo the transformation of the divine into a material place:

'The portrait recalls the icon and resembles it in much the same way as the absence of presence recalls, so as to resemble the presence of an absence. It recalls, in the finite character of each, the infinite distention of the one' (Nancy, 2006: 241).

The singularity of the person in the portrait echoes the indivisibility of the monotheist God, to the extent that the portrait is the presentation of his or her absence, the mark of the singularity of the absent person. All images show the singularity of the object in its absence, but this is not because they are directly determined by the absence of the monotheist God. If that were to be the case, then it would be the same as an affirmation of a pre-existing, i.e. mythological, God. Instead, Nancy demonstrates the strong co-determination, or resonance, between the religious definition of the image (as related to the abandonment of the religious mode) and our contemporary and secular notions of what 'image' and 'representation' mean. This internal rift, or opening, in the notion of representation manifests itself in contemporary anxieties concerning the status of representation. According to a later line of analysis developed by Nancy in 'The Vestige of Art' (1997), contemporary art - with its continuous anxiety concerning the status of representation - would find itself surprisingly close to the demand for 'a vision other than that of sight'.

\section{Representation}

At this point it seems important to sketch how Nancy frames the question of representation in 'Forbidden Representation' (Nancy, 2005b). Here, he argues that the prohibition on representation, which is central to some versions of monotheism, is not to be understood as belonging to the regime of iconoclasm nor does it properly speaking belong to an abstention from images. Instead, this question concerns idolatry and not the image as such. The idol is not an image of God, but is itself a fabricated god, and the false character of its divinity derives from the fact that it is a fabrication. It is valued for itself and not for what it represents, because it is an image that is itself considered to be a divine 
presence (Nancy, 2005b: 30). However, as Nancy indicates, the Jewish god has 'no form at all' and therefore:

'[...] has no image either. He has no other resemblance other than that of a man, but this is neither a resemblance of form, nor one of content (man is therefore made in the image of that which has no image)' (Nancy, 2005b: 30).

Therefore, what is forbidden in the Jewish tradition is not the image as being an 'image of', but rather the idol, which asserts its presence only through itself as 'a pure presence in a certain sense, a massive presence' (Nancy, 2005b: 31). In other words, the idol is not attacked for being an imitation, but because it asserts its full and heavy presence from which 'nothing departs or withdraws' (Nancy, 2005b: 31, my emphasis AA).

For Nancy, the prohibition on representation should not be seen as the result of God's jealousy of other false and fabricated gods, as stated in the Old Testament, but rather as relating to certain aspects of the monotheist notion of creation. The suspicion attached to the graven image is related to its fabricated nature and to it being an imitation of a pre-existing original. In Nancy's view, the existence of something given and primordial clearly belongs to the mythological mode, to the regime of the foundational myth characteristic of polytheism (Nancy, 2007: 69). In this sense, the idol viewed from a monotheist perspective is a result of an invention of a god as the model for the image. In other words, the production of idols is a fabrication of gods by man. However, within the monotheist perspective, as Nancy interprets it, creation does not have any model: it is the world itself. Seen in that light, the ban on graven images, on the production of idols, is not the result of the visual inaccessibility of God (it would be impossible to have a sensible representation of something that cannot be seen), but of the very structure of creation that is not carried out by a producer and is absolutely without a model. This ban can be interpreted as a moment in which monotheism forbids not the image as such, but the fabrication of gods, or production in the mythological mode, according to a foundational myth. In this sense, the prohibition on representation is a decisive moment in the separation of polytheism from monotheism, as well as the autodeconstruction of monotheism, insofar as the departure from a pre-existing model is a key moment in it. In other words, monotheism departs from the religious mode insofar as God is indivisible from the world in monotheism, and such indivisibility is actually a withdrawal, an absent presence. As a result, the monotheist iconoclasm involves a condemnation of images, because it presupposes 'a certain interpretation of the image as a closed presence... opened onto nothing' (Nancy, 2005b: 31, my emphasis AA). 
Nancy further argues that in Western history, the theme of the image as deceitful and weak resulted from "...the alliance forged between the principle of monotheism and the Greek problematic of the copy or the simulation, of article and the absence of the original." (Nancy, 2005b: 31) In order to understand the problem of representation, in Nancy's view, we have to be attentive to this alliance 'constitutive of our history' (Nancy, 2005b: 32). On the one hand, this alliance involves a monotheist God who does not challenge the image, 'but who gives his truth only through the retreat of his presence - a presence whose sense is an absence', and on the other hand, it involves the Greek notion of the image as a copy, as a simulation of an absent original (Nancy, 2005b: 32). The absence of a withdrawing God "condemns the presence that offers itself as the completion of sense" (Nancy 2005b: 32) in the idol, but the image is also considered as a mere degraded reflection of the original. The effects of this double motif are present in our understanding of art:

'[...] within what has since the Renaissance gradually come to be named "art", [...] what will always have been at stake is the production of images [...] that are exactly the opposite of making idols and exactly the opposite of an impoverishment of the sensory: not a thick and tautological presence before which one prostrates oneself but rather the presentation of an open absence within the given itself [...] of the so-called work of "art". This presentation is called representation in French. Representation is not a simulacrum; it is not the replacement of the original thing - in fact it has nothing to do with a thing. It is the presentation of what does not amount to a presence, given and completed' (Nancy, 2005b: 32-33).

In Nancy's interpretation, the Western notion of representation is inextricably linked with the monotheist withdrawal of God. Representation contains this absence at its centre, as opposed to the immediacy of the 'being-posed-there' (Nancy, 2005b: 36), and it never simply reproduces an original, which is absent. Instead, 'it presents what is absent from presence pure and simple'. In order to flesh out this idea, he differentiates between the 'absence of the thing', which would be related to 'the problematic of its reproduction' and the 'absence within the thing', which would be related to 'the problematic of its [re]presentation' (Nancy, 2005b: 37). In this way, Nancy tries to show how our contemporary understanding of the notions of image and representation, is in fact conditioned by the auto-deconstruction of monotheism. The tracing of such diverse meanings is indicative of the scope of the project of a deconstruction of monotheism and Christianity. As Nancy conceives it, such a project does not limit itself to being a commentary on religious themes as such, but is concerned with their implicit presence in different cultural realms. Representation understood as conditioned by a radical 'absence within' gives way 
to a notion of an open image (and, as Nancy insists, not only in Christian art, but also in the art of the modern world), an image that does not portray in a univocal manner. It is an image whose only model is precisely the absence of a model. It is the withdrawal of God in his creation ex nihilo, the indivisibility between the world and God - an open, auto-deconstructive image.

In the context of Nancy's deconstructive project, art and monotheism have to be thought of as co-originary, where art - or the image - gives monotheism invisibility as a negative and yet paradoxically sensible modality of the withdrawal of God. In turn, monotheism gives art the internal opening towards indefinite sense that results from such withdrawal. The auto-deconstructive, open image is one of the places where religion retreats from religion. The image becomes the mark of that retreat. The singularity of each image or artistic gesture, or the uniqueness of the work of art, echoes the ex nihilo of creation. This would be one of the ways of understanding Nancy's thesis that art is at the heart of the auto-deconstruction of Christianity (Nancy, 2005c: 140, note 4). The subsequent development of this idea in Nancy's writings on visual art is closely related to his radical rethinking of the Christian idea of incarnation.

\section{Incarnation - The Body as an Image}

In an essay entitled 'Verbum caro factum', Nancy identifies the Christian idea of incarnation, or the formula 'by which God makes himself man' (Nancy, 2005a: 125), as a decisive aspect of the movement of Christianity towards its own deconstruction. The term 'incarnation' can be understood in two ways. Generally, it refers to the entering of a incorporeal entity into a body and implies that the body is defined as a place occupied by an invisible soul or spirit. Understood in this way, it can mean 'representation', where the body is defined as a sensible manifestation (Nancy, 2005a: 125). In contrast, incarnation' - in the theological sense of the term - refers to the idea that the Word itself became flesh, which resulted in one person with two heterogeneous natures. In this second sense, the Christian body would not be a material exteriority inhabited by the soul, but a spirit that moves out of itself, its pure identity, in order to identify itself as human (Nancy, 2005a: 126). According to Nancy's interpretation, the Christian God reveals himself through and in creation, whereby creation has nothing to do with a fabrication or production according to a pre-existing model. It is precisely a 'putting-outside-oneself' (mise-hors-de-soi) (Nancy, 2005a: 127), the emptying oneself in the moment of creation (the theological motif of kenosis). In this sense, the Christian God is a God who 'alienates himself' from himself, i.e. the becoming empty of 
God. Consequently, the body itself becomes the name of an 'atheised' God who is precisely the opposite of an immediate and self-sufficient presence (as that of the idol). As Nancy phrases it, the Christian body is 'the taking place, the event, of the disappearance' of the withdrawal of the monotheist God (Nancy, 2005a: 127).

In the context of Nancy's thesis that monotheism is an atheism, incarnation can be interpreted as the idea of the final dissolution of God into the world and his becoming a man. It signifies the alteration of a transcendent God, which places God and humans in a relationship that exceeds the 'drama of resemblance' between creator and creature (as set out in Genesis), because it defines God as human. The body after the incarnation, if Nancy's interpretation can be extended a little bit further, is not created in the image of God, but in the image of the absence of a model. As Nancy points out in Corpus (2000), the creator cannot be thought of as reproducing his image. Instead, his power resides in the initial deconstruction of any recognisable image, since the created world does not imitate anything else but the inimitable. As Nancy phrases it, the body is the plastic matter that spaces out without form and without idea. It is motion, modalisation, a coming into presence. The body after incarnation, and to an equal extent the 'humanism' that Nancy refers to as a founding condition of Western culture, incarnates nothing but the very model-lessness of creation. Within the context of Nancy's project of a deconstruction of Christianity, the body becomes the place where the allo-auto relationship of monotheism, and particularly Christianity, is played out. In Nancy's view, the incarnation can be understood as the auto-mimesis of man who creates God in his own image, as well as the initial absence of a model in creation, i.e. the complete alienation of God from himself. The idea of the incarnation constitutes a double moment within the auto-deconstruction of monotheism. It gives way to the sensible representation of the divine in animage while simultaneously making the image atheistic - the image of God is a man: God as indistinguishable from man.

Such a line of thinking resonates strongly with the interpretation of the incarnation and its significance to art given by Georges Didi-Huberman in Confronting Images: Questioning the Ends of a Certain History of Art (2005). He argues that although Christian art can generally be envisaged in the context of mimetic representation, an imitation inherited from the Greco-Roman world, such notions tend to ignore their own limitations by blocking the access to their own crises. Instead, it is important to consider Christian art within the power of the complex and open word incarnation, which implies alteration rather than imitation (Didi-Huberman, 2005: 184). Incarnation altered the 
sameness of the transcendent god in order to be able to think the drama of the arch-resemblance, i.e. that between God and man, which is a drama that turned around the death of the god-image required by his very incarnation (DidiHuberman, 2005: 211). In his view, incarnational images are desire-images, since they constitute a paradigm, a matrix of relationships in which man tried to think of himself in the as an image of his God.

In the interpretation of Nancy and Didi-Huberman, there is an overlap between the allos of the monotheist God and the 'auto-' of the relationship of humans with themselves. It is precisely this mode of self-relationship that can be identified as one of the main features of the auto-deconstructive aspect of monotheism. In the case of incarnation, this 'auto-'is the moment of the auto-mimesis of man, who creates God in his image. And vice versa, as Didi-Huberman puts it: it is the moment of man thinking of himself in God's image. Giving God a body makes it possible to have a representation of the divine in the body of a man. However, it also introduces a complication that does not allow the image to be a mere imitation of the God-man, for the representation of God would in fact be a representation of a man. As Didi-Huberman points out in Fra Angelico. Dissemblance and Figuration (1995), this is the issue of how to distinguish sacred from profane bodies in the image (Didi-Huberman, 1995: 6), and - in a broader sense - between sacred and non-sacred images. The necessity of making such a distinction makes it impossible for the image to remain within the illustrative or figurative mode. In the paintings of Fra Angelico, the sacred image distinguishes itself through what Didi-Huberman calls a 'zone of relative disfiguration' (Didi-Huberman, 1995: 27), i.e. a part of the painting that exceeds the mimetic mode of representation. With the notion of 'the distinct', Nancy articulates a similar issue related to the way in which images convey the sacred. However, in contrast to Didi-Huberman, he claims that the distinct is an aspect of every image and at the same time the moment of demonstration of the sacred as well as the abandonment of the religious mode.

\section{The Distinct}

After identifying the effects of the monotheist withdrawal of God on the notion of representation in 'Forbidden Representation', and how Christianity further complicated that formula by giving a body to that withdrawal, I will now focus on the recurring themes of force, intensity and materiality in Nancy's essays on visual art. These themes should be understood in the light of his deconstructive rethinking of the incarnation. For instance, in 'The Image, The 
Distinct' (2005c), he differentiates between 'religion' and 'the sacred' in order to articulate an aspect of the image which he calls 'the distinct'. He argues that while religion is related to 'observance of a rite that maintains a bond, the sacred, signifies the separate, what is set aside, removed, cut off' (Nancy, 2005c: 1). Whereas religion can still be considered as securing a bond with the separated sacred, 'there is no religion of the sacred', because the sacred is 'what one cannot touch (or only by a touch without contact)' (Nancy, 2005c: 1). Nancy calls this type of sacred 'the distinct'. The possible inconsistency with which he uses such terms as 'religion' is partially resolved by his thesis that monotheism itself moves toward the abandonment of the religious mode. Nancy uses the term 'sacred' or 'distinct' to designate the double moment contained within the idea of incarnation - the making possible of the representation of the divine, and the atheism of the image. In Nancy's interpretation, as we have already seen, the monotheist God is characterised mainly by his indivisibility (which is different from his invisibility, as traditionally understood), which is not the result of a numerical reduction in the number of gods, but rather of his indistinguishability from the world. The image is distinct precisely because it is the mark, or the trace, of that withdrawal of God. It testifies to his indistinguishability both from the world and from the body. Such understanding of the image, Nancy writes, is very close to:

'[...] the Christian God, and particularly the Catholic God, [who] will have been the god of the death of God, the god who withdraws from all religion (from every bond with a divine presence) and who departs into his own absence, since he is no longer anything but the passion of the intimate and the intimacy of suffering or of feeling and sensation [...]' (Nancy: 2005c, 11).

In order to expand upon the notion of the distinct in more detail, Nancy refers to the religious theme of sacrifice as 'a legitimized transgression', or as lifting the profane into the sacred (Nancy, 2005c: 3). However, he immediately differentiates the notion of the image from the act of consecrating, or of making sacred, which is something that cannot be done, since the sacred has to come from elsewhere, i.e. from the depth of a withdrawal (which would be the withdrawal of God). The distinction of the image deconstructs sacrifice insofar as it 'does not legitimize and it does not transgress: it crosses the distance of the withdrawal even while maintaining it through its mark as an image' (Nancy, 2005c: 3, my emphasis AA). Nancy insists that the image is simultaneously a withdrawal and a passage, a rapport or a relationship, an exposed intimacy. It is not a depiction, an illustration or a translation of its subject, or 'the soul'. On the contrary, 'it is the soul itself that presses and pushes on the image; or rather 
the image is this pressure' (Nancy, 2005c: 6). In this sense, the image exceeds representation.

On the basis of the discussion so far, several aspects of a notion of an autodeconstructive image can be identified in Nancy's essays on the image and visual art. The notion depends upon, or is at the very least developed in parallel with, the project of a deconstruction of monotheism and Christianity. The first of those aspects is the absence posited at the heart of representation. This absence 'within the thing' would be one of the effects of the withdrawal of the monotheist God. But Nancy goes one step further by explicitly using the term 'image' in 'The Image. The Distinct', arguing that it exceeds representation, in the sense that the image becomes the very intensity of the material place, the mark, the stigma. This would be the second aspect of the auto-deconstructive image, which is conditioned by his rethinking of Christianity and in particular of the incarnation as its central doctrine. If representation is to be understood as a presentation of an open absence that is informed by the motif of the withdrawal of God, which according to Nancy can be identified as one of the central auto-deconstructive aspects of monotheism, then the image, or the distinct - as he calls it - is related to the Christian motif of a God who withdraws from all religion, a God whose incarnation, becoming a body, in fact marks the disappearance of God, and it is such bodily materiality that gives way to images. This emphasis on the materiality of the image, as well as its contagious presence, is closely related to Nancy's rethinking of the incarnation. He notes that the image can be understood as a 'real bodily presence' in the Christian sense of the expression. It would not be the ordinary presence "not the god present in the world', but the sacred or distinct 'intimacy that a fragment of matter gives to be taken in and absorbed. It is a real presence because it is a contagious presence' (Nancy, 2005c: 11).

\section{Visitation - Christianity as Painting}

A central thesis in 'Visitation: Of Christian Painting' (Nancy, 2005d), in which Nancy focuses on the painting of the same name by Jacopo Pontormo, is that Christian images cannot be reduced to the illustrations of biblical stories and that art cannot be placed in a position of being a medium of a memory: 'Art never commemorates. It is not made to preserve a memory [...]' (Nancy, 2005d: 108). This essay is not an (art) historical analysis of Pontormo's painting, (although Nancy does mention the historical context in which it was created), but is rather an attempt to think the event of this painting, which exceeds its narrative aspect (i.e. being a painting about the story of the visitation of 
Elizabeth by Mary). Nancy argues that the Christian painting is not a representation of a Christian subject. Any image can successfully convey a story, but that does not make it an artistic image. On the contrary, the more it identifies with the illustrative mode, or the more 'pious' it is, the more it is crushed by its subject matter. Christian painting is itself Christianity, 'or something of Christianity in painting or as painting' (Nancy, 2005d: 122).

Didi-Huberman makes a similar observation with respect to the paintings of Fra Angelico. He claims that his paintings do not claim to be visual translations of Christian stories, i.e. they are neither narrative nor illustrational. Instead, they belong to the world of exegesis (etymologically: leading out of), producing networks of associations and sacred meanings. This non-representational strategy was employed by the painter in order to translate in pictorial terms the mystery of the incarnation, which determines (although only to some extent) the figurative aspect of Christian images - they are almost always corporeal representations. Fra Angelico found a way to render the mystery, to locate the properly sacred aspect of his paintings in a network of dissemblances, in the 'pictorial poetics of blotches and traces' (Didi-Huberman, 1995: 7). Precisely this indexical, material aspect of his paintings, the "visual and colored intensity $[\ldots]$ sought presence before representation', and did not define the painting as a window to the world (the traditional mimetic notion of the image). Thus the religiosity of Fra Angelico's paintings is not to be found in its representational or narrative aspect (there is no such thing as a religious image for Nancy), but in the way it highlights its own materiality, in the very intensity of the coloured places. Such images hide no other invisibility than the intensity of their presence.

Along similar lines, Nancy concludes in 'Visitation' that Christian paintings indicate what is at stake in Christianity insofar as they are representations of the divine: they actually abandon the religious mode. The paintings themselves announce the withdrawal of gods, they are 'the atheism of that withdrawal', because they expose the very material place 'selfsame with the canvas' (Nancy, 2005d: 123), beneath which there is nothing hidden and 'no god is waiting except the place itself' (Nancy, 2005d: 123). In this sense, Christian paintings are the moment of visual announcement of the separation from the mythological mode of polytheism. After the image-less God of monotheism, they paint the very metamorphosis of the divine into a place. The image is in fact "the there of a beyond. It is not at all its "representation": it is a thinking-there, thinking as the effectivity of a place opening itself to presence" (Nancy, 2005d: 125). In sum, Nancy does not give painting a role in something that would mediate Christian self-overcoming, but allocates it a position where it is itself 
an overcoming, its place or rather its event, its taking place. This line of analysis is informed by a radical rethinking of the incarnational formula and displaces the properly religious element in what is generally referred to as Christian art. Nancy writes that 'every mode of painting' being incessantly exposed to the withdrawal of God, and to 'real presence' that 'is par excellence not present' actually embodies, or shares, the becoming body of God and its aporias (Nancy, 2005d: 123). As a result, every image exposes such atheism and incessantly reflects upon the limits of representation and the representation of those limits. By perpetually presenting its body to us, it exposes the anarchic formula of self-creation.

\section{Bibliography}

(The Bible. Revised Standard Version, http://etext.virginia.edu/rsv.browse.html (accessed: 20 January 2008).

Hans Belting, Likeness and Presence: A History of the Image Before the Era of Art, trans. byEdmund Jephcott, Chicago: University of Chicago Press (1997).

Georges Didi-Huberman, Fra Angelico. Dissemblance and Figuration, trans. by JaneMarie Todd, Chicago: The University of Chicago Press (1995).

Georges Didi-Huberman, Confronting Images: Questioning the Ends of a Certain History of Art, trans. by John Goodman, Pennsylvania: The Pennsylvania State University Press (2005).

Joseph Leo Koerner, 'Icon as Iconoclash', in Iconoclash: Beyond the Image Wars in Science, Religion and Art, ed. by Bruno Latour and Peter Weibel, Cambridge, Massachusetts: The MIT press (2002).

Marie-José Mondzain, 'The Holy Shroud: How Invisible Hands Weave the Undecidable', in Iconoclash: Beyond the Image Wars in Science, Religion and Art, ed. by Bruno Latour and Peter Weibel, Cambridge, Massachusetts: The MIT press (2002).

Jean-Luc Nancy, 'The Vestige of Art', in The Muses, trans. by Peggy Kamuf, Stanford: Stanford University Press (1997).

Jean-Luc Nancy, Corpus, Paris: Editionsié (2000).

Jean-Luc Nancy, 'Deconstruction of Christianity' in Religion and Media, ed. by Hent de Vries and Samuel Weber, Baltimore: Johns Hopkins University Press (2001).

Jean-Luc Nancy, 'Deconstruction of Monotheism', in Postcolonial Studies 6:1 (2003). Jean-Luc Nancy, La déclosion. Déconstruction du christianisme I, Paris: Galilée (2005a).

Jean-Luc Nancy, 'Forbidden Representation', in The Ground of the Image, trans. by Jeff Fort, New York: Fordham University Press (2005b).

Jean-Luc Nancy, 'The Image. The Distinct', in The Ground of the Image, trans. by Jeff Fort, New York: Fordham University Press (2005c). 
Jean-Luc Nancy, 'Visitation: Of Christian Painting', in The Ground of the Image, trans. by Jeff Fort, New York: Fordham University Press (2005d).

Jean-Luc Nancy, 'The Look of the Portrait', in Multiple Arts. The Muses II, ed. by Simon Sparks, Stanford: Stanford University Press (2006).

Jean-Luc Nancy, Creation of the World or Globalization, trans. by François Raffoul and David Pettigrew, New York: State University of New York Press (2007).

Alena Alexandrova is a $\mathrm{PhD}$ candidate, University of Amsterdam, the Netherlands. She is currently completing a thesis which examines how contemporary art critically re-appropriates religious themes and motifs. She has published articles on contemporary art and dance theatre drawing on Jean-Luc Nancy's writings on art. She is also a co-editor of the volume Retreating Religion: Deconstructing Christianitywith Jean-Luc Nancy. A. Alexandrova@uva.nl Address: Elandsstraat 140, NL-1016 SJ, Amsterdam. 